\title{
The role of human resource costing in assisting investors to appraise the human assets of a business enterprise
}

\author{
Alnasser Nabil Mahmoud, Shaban Osama Samih, Atieh Abdallah K \\ Accounting Department, Al-Zaytoonah University of Jordan, Amman, Jordan \\ Email address: \\ nnasser@offtec.com (A. N. Mahmoud), shaban_osama@hotmail.com (S. O. Samih), abedatia@yahoo.com (Atieh Abdallah K)
}

\section{To cite this article:}

Alnasser Nabil Mahmoud, Shaban Osama Samih, Atieh Abdallah K. The Role of Human Resource Costing in Assisting Investors to Appraise the Human Assets of a Business Enterprise. International Journal of Economics, Finance and Management Sciences. Vol. 2, No. 2, 2014, pp. 117-122. doi: 10.11648/j.ijefm.20140202.11

\begin{abstract}
This research study aims to contribute in modifying the current accounting practice through recognizing investments in human resources as an asset cost. The current study try to explain that, the original cost of human resource is the sacrifice that was actually incurred to acquire and develop people. The current accounting practices for human assets causes an important problem to investors and management, because it distorts the measurement of return on investment. The study concluded that in order to apply an actual human resources accounting system, companies should use the human resource costs concepts and measurements techniques in a good and effective manner while planning for its costing system.
\end{abstract}

Keywords: Human Resource Costing, Human Resource Accounting, Allocating Human Resources, Measuring Investment

\section{Introduction}

Human recourse accounting is not a new issue. The true research into human recourse accounting began in the 1960s, as many economists believed that human capital is an important production factor, and they explore different ways of measuring its investment in education, health, and other areas; i.e. Human Resource Development.

Human resource costing means accounting for people as an organizational resource. It involves measuring the costs incurred by business firms and other organizations to recruit, select, train, and develop human assets. It also involves measuring the economic value of people to organizations [1].

The primary purpose of a human resource costing system is to help management plan and control the use of human resources effectively and efficiently. In addition, some human resource costing information may also be reported in financial statements for use by investors and other outside parties of the organization [2].

The best way to understand the role of human resource accounting in satisfying management and investors information needs is to examine the actual operations of such a system in a business.

The competitive position of a firm depends on its specific and not duplicated assets [3]. The most specific assets that an enterprise has are its personnel. It takes advantage of their interdependent knowledge. That would explain why some firms are more productive than others.

Human resource accounting means accounting for people as organizational resources. It is the measurement of the cost and value of people to organizations [4].

A primary objective of accounting for human resources is to help facilitate the effective and efficient management of people. Human resource accounting is also intended to assist present and potential investors. It provides investors with information about the ways management builds and depletes human assets [5].

The importance of a proper costing system for human resources can be embodied in the following two points. First, people are a valuable resource to a firm so long as they perform services that can be quantified. The firm need not own a person for him to be considered a resource. Second, the value of a person as resource depends on how he is employed. So management style will also influence the human recourse value [6].

In this research we are going to treat the topic from basic theory to practice and its applications in business enterprises The research will examines the role of the human resource accounting in the process of managing people in organizations and its role in assisting investors to appraise the human assets of a business enterprise. 


\section{Literature Review}

Human resource costing is a tool designed to assist in the effective and efficient management of human resources. Human resource management is a system designed to transform human resource inputs into outputs (human services). The inputs are people: individuals, groups, and the total "human organization." The transformation processes are managerial sub-systems for acquiring, developing, allocating, and conserving, utilizing, evaluating, and rewarding people. The outputs are the services provided by individuals and groups. These services are the basis of the value of people to an organization. Thus we can say that the ultimate purpose of human resource management is to contribute to the value of an enterprise as a hole by transforming "raw" human inputs into valuable human outputs [7].

From management's perspective, the primary role of human resource costing is to provide information necessary to perform the functions of acquiring, developing, allocating, conserving, utilizing, evaluating, and rewarding human resources. This means that management needs various types of information to perform the human resource transformation process. Human resource costing can helps management with each of the following functions.

\subsection{Acquisition of Human Resources}

The acquisition of human resource involves recruiting, selecting, and hiring people to meet the organization's present and expected future manpower needs. The first step in human resource acquisition is to forecast manpower requirements; when they have been forecast, management must translate its personnel needs into a manpower acquisition budget. This is essentially a process of cost-estimation [8].

Human resource costing can be useful in budgeting manpower acquisition. It can provide measurement of the stand cost of recruiting, selecting, and hiring people, which can be used to prepare proposed manpower acquisition budgets.

Personnel selection is another process in which human resource costing can play an important role through making selection decisions. Managers need measurements of the value of alternative jobs of candidates. A personnel manager, for example, faced with a choice among several attractive candidates for a job, would ideally want to choose the person possessing the greatest future value to the organization. However, measurements of the expected value of people are not presently available, and if it is available, personnel managers could use decision rules designed to optimize the expected value of an organization's human resources [9].

\subsection{Development of Human Resources}

The development of human resource involves various forms of training designed to enhance the technical, administrative, and interpersonal skills of people. This, in turn, increases their value to an organization. Development may occur through formal programs or on-the job learning [10].

Management faces two problems in budgeting human resource development, first is to allocate the human resources cost, and second, to estimate the cost of the proposed expenditure. The former is a resource allocation decision, while the latter is a problem of cost estimation.

Human resource costing can help in facilitating decision making throughout the allocation of resources and measuring the expected rate of return on proposed investment [11]. Human resource costing can also be useful to management in formulating policy for human resource acquisition and development. By providing estimates of the historical and current costs to acquire and develop people for the various positions, human resource costing can help management assess the trade-offs between the costs of recruitment from outside and development needs to assist in formulating personnel acquisition and development policy [12].

\subsection{Allocation of Human Resources}

"The allocation of human resources is the process of assigning people to various organizational roles and tasks" [13]. There are several objectives involved in allocation decisions. First, the task to be performed should be completed in the most efficient way. This means that management will choose the right person to right place. Second, an organization's human resources should be developed and well trained. Third, management wants to allocate people to jobs, which satisfy their needs. Thus management allocates people to jobs in a way that will optimize these three variables: job productivity, human resources development, and individual satisfaction.

\subsection{Conservation of Human Resources}

Conservation of human resources is the process of maintaining the capabilities of people as individuals and the effectiveness of the human system developed by an organization. Capabilities of human resources should be always monitored and maintained otherwise it will deteriorate. In other words an organization will have to incur either training costs or replacement cost to rebuild its human capabilities. Similarly, management must monitor the effectiveness of the human organization that has been developed to assess the extent to which it is being maintained or developed.

Failure to measure the extent to which human resources are being conserved in a division, plant, or department can be costly to an organization. In the short run, for example, a divisional manager can put pressure on people temporarily to increase their productivity or reduce costs, with the effect upon employee motivation, attitude, and labor relations going unmeasured. As a result, highly trained and skilled employees become dissatisfied and leave an organization. The cost of replacing them may be costly [14].

Management must account for an organization's human 
assets in order to prevent their depletion. Currently, an organization's conservation of its human resources is measured in terms of turnover rates. Measures of turnover, however, are inadequate indicators of human resource conservation for two reasons. First, they are historical and therefore unavailable to management until after turnover has occurred. Thus they cannot be used as an early-warning signal to suggest the needs for special efforts at conservation. Second, turnover rates do not fully represent the economic impact of turnover, which is mostly represented by monetary measures embodied in the economic value derived by the difference between the replacement cost and the un-amortized investment spent by an organization.

Human resource costing can assist management in conserving its human organization by providing an early-warning system. It can measure and report certain indicators of the condition of the human organization, and management can assess trends in these variables prior to the actual occurrence of turnover.

\subsection{Utilization of Human Resources}

Human resource utilization "is the process of using human services to achieve organizational objectives" [15]. Human resource costing can help managers to utilize human resources effectively and efficiently by providing a conceptual framework for human resource utilization. Also it can provide a framework to help managers utilize human resources effectively and efficiently. This belief involves thinking of human resource acquisition, development, allocation, and conservation as strategies designed to influence the value of people.

\subsection{Evaluation and Rewarding of Human Resources}

In job evaluation terminology the word size is used to indicate the relative significance of a job to the organization. The primary purpose of job evaluation is to provide a rational basis for the determination and management of internal relatives between jobs. It involves assessing of the value of people to an organization. And also involves measuring the productivity, and development of people [16].

Human resources costing can be useful in the human resource evaluation process by developing valid and reliable methods of measuring the value of people to an organization. These methods will include both monetary and non-monetary measurement. They will permit human resource management decision to be made on a cost-value basis.

Human resource valuation will also have an impact on the rewarding system of the organization. These systems are intended to motivate and reinforce the optimal performance of people in achieving organizational objectives. Human resource valuation will permit organizational rewards to be administered in relation to a person's value to an organization. It will enable management, for example, to base compensation decisions on the value of people to a firm.

\subsection{Overall Function of Human Resource Costing}

From a managerial perspective, human resource costing has a dual purpose. It represents the way that management thinks about the human resources. It proposes that management base its human resource management decisions on a cost-value calculus; that is, on an assessment of the cost and value involved in a decision. Human resource costing is also a system of providing management with the information needed to manage human resources efficiently. It provides information about the cost and value of people to an organization, with the specific needs of a given organization determining the types of information provided.

Although human resource costing is intended primarily as a management tool, it also has significant uses for external users of corporate financial statements especially for investors. This is because present and potential stockholders of a company are also interested in obtaining information about an organization's human assets in addition to other financial assets. This information would assist them in making decisions to acquire, retain, or dispose of stock.

Unfortunately such information is not available to investors. At present, financial statements prepared in accordance with "Generally Accepted Accounting Principles" do not indicate the value of any of an organization's assets. In addition, financial statements do not inform investors of an organization's investment in human assets, because conventional accounting treats investments in human resources as "expenses" rather than as "assets".

\subsection{Investment in Human Resource Accounting}

The concept of investment in employees; the human capital of the organization, push forward a view that one is looking for a profit to be gained from the investment and therefore the focus is on the development of employees for a specific purpose to gain monetary benefits. Optimizing of profits would result only if the organization develops clear and comprehensive strategies and initiative for the training and development of its employees[17]. Investment in professional training is often treated as an industrial relation activity, and not as an essential investment decision like for the acquisition of plant or technology. When we consider human assets costing, the under lined idea is, we are considering the human inventory stock of a company incorporated available to the organization to perform the activities. A company is a person or persons associations of persons for trade. The company law provides and lays conditions to disclose the fair and true position of the state of affairs of the company, required to be certified by auditors, and concealment of many material fact is treated as violation and a punishable offence. The inventory cost, its basis of valuation, the investment in shares; its marketable cost, and all that is necessary for financial evaluation is required to be disclosed, except the people, the human capital conducting the affairs of that company without which the company in factual terms is nothing but merely a title. The organization 
of universal reputation is recognized besides other factors, due to the persons working for the same, but this hard fact is missing from the balance sheet and financial statements [18].

\subsection{Effects of Current Practice on Investment Decisions}

From the viewpoint of both management and investors, current accounting practice for human assets causes an important problem because it distorts the measurement of return on investment. The concept of rate of return is crucial variable in management and investor decisions, since rate of return is the ratio of net income to total assets, it becomes

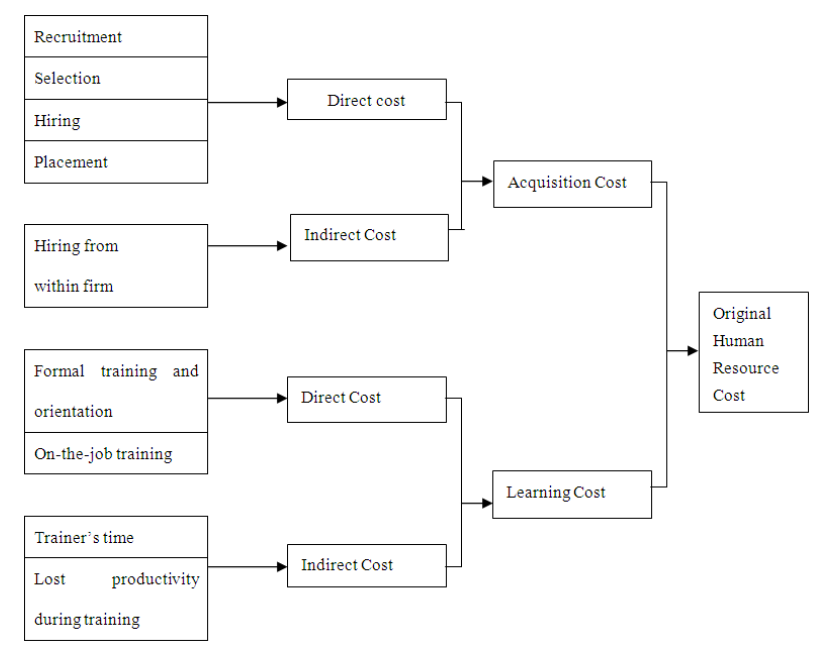

Figure 1. Model for Measurement of Original Human Resource Cost. (Source: Eric G. Flamholtz, (1999) Human Resource Accounting.)

\section{The Measurement System}

The system developed to account for the investments made in the firm's managerial resources is shown schematically in the following figure (1). The total costs of the firm are first classified into two components: human resource cost and other cost. The human resource costs are then separated into their expense and asset components. For a cost to be treated as an asset, it must be expected to provide benefits to the company beyond the current accounting period. If its benefits are expected to be fully consumed during the current period, it is treated as an expense. The human assets are then classified into functional categories such as recruiting, acquisition, information training, and development. These functional costs are traced to specific individuals and recorded in individualized accounts for accounting department. Rules and procedures have been developed to depreciate these investments over their expected future service life [20].

There are seven functional accounts for exempt personnel in one system:

1. Recreating outlays costs: These costs are associated with locating and selecting new personnel, such as, search fees, advertising, interviewer, allocation of personal and acquiring department time for internal distorted because the distortions in its components [19]. Investors who wish to base their decisions on an organization's rate of return must attempt to adjust for investments in human assets.

\subsection{Measurement of Original Cost of Human Resources}

The following model represents an attempt to measure the original human resource costs. It identifies the two basic elements of original cost: acquisition costs and learning costs. Each of these elements has both direct and indirect costs components, as it is described below.

screening and interviewing and testing and evaluation expenses.

2. Acquisition costs: these costs are incurred in bringing new management personnel or ordinary personnel to the group. This category includes placement fees, moving costs, physical examination, allocation of personnel, and acquiring department time in placing a man on the payroll and situating him with the necessary equipment to perform his job.

3. Formal training and familiarization costs: These costs are normally incurred immediately after hiring the personnel. They refer to formal orientation program, vestibule training etc.

4. Informed training cost: These costs are associated with the process of teaching a new person to adapt his existing skills to his new job. The costs related to this process are normally salary allocations only.

5. Informal familiarization costs: These costs are associated with the very complex process of integrating a new manager into the organization to the point where he can be a fully effective member of the organization. Such costs include learning the company's philosophy, history, policies, objectives, communications patterns, past practices, understanding of people with whom the new position holder regularly interacts.

6. Investment building experience costs: These costs include the investment in on the job learning which occur after the initial familiarization period, which are expected to have value to the company beyond the current accounting period.

7. Development costs: These costs are associated with investments in increasing a manager's capabilities in areas beyond the specific technical skills required by the position. In this category costs are management seminars, university programs or courses.

\section{Study Hypotheses}

H01: There is no significant relationship between human resource costing system and its role in assisting investors to appraise the human assets of a business enterprise.

H02: There is no significant relationship between human resource costing system and the measurement of return on Investment ROI. 


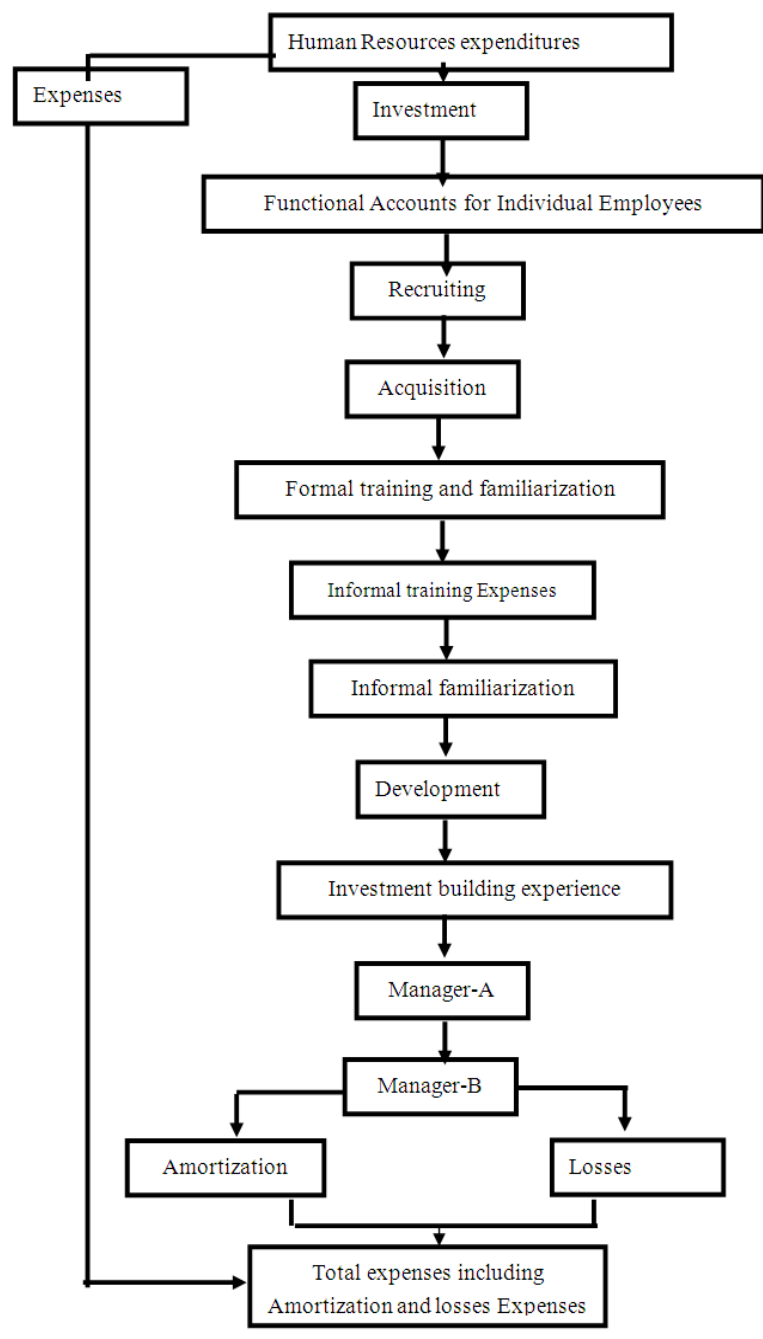

Figure 2. Schematic Model of Human Resource Accounting System for Investment in Individual

\section{Research Methodology}

The research was carried out by primary data, collected by using a structured questionnaire, carried from a combination of Jahmani and Al-Omari [21], and Hijazi and Ma'alem [22] studies that were implied on other sectors, and the data was analyzed by using SPSS software. The first part of the questionnaire contained the demographic factors which were education, working position, experience. While the second part measured the relationship between human resource costing system and its role in assisting investors to appraise the human assets of a business enterprise, and the relationship between human resource costing system and the measurement of return on Investment ROI.

The scale of measuring was Likert type (five-point scale), and answers were ranged between highly agree, agree, somewhat agree, disagree, and highly disagree.

The reliability test was applied to examine the internal consistency of the research instrument. The Cronbachs' alpha coefficient was (.92) which confirms the reliability of the questionnaire.

\subsection{Research Population and Sample}

The study community is formed out of the traders in Amman Stock Exchange Market as they form the potential investors in the public sector. 50 copies of the questionnaire were delivered by hand on the respondents, 36 copies were returned (percentage of $72 \%$ ); these 36 copies were accepted and used in the pilot analysis of the original distributed copies, Table (1) shows these results.

Table 1. Research Population.

\begin{tabular}{lll}
\hline Items & No. & Percentages \\
\hline Questionnaires Distributed & 50 & $100 \%$ \\
Questionnaires recovered & 36 & $72 \%$ \\
\hline
\end{tabular}

\subsection{Methods of Data Analysis}

The descriptive and analytical statistical techniques were applied in the analysis by using mean, standard deviation, percentage and frequency. Also t-test was applied to test the study hypotheses.

\section{Findings and Hypothesis Testing}

\subsection{The Reliability Test}

Cronpanch Alpha was used to test the reliability of the scale and it was (0.92) which is good because it's higher than the accepted percent (0.60). Table-2 illustrates these results.

Table 2. Reliability Statistics.

\begin{tabular}{lll}
\hline $\begin{array}{l}\text { Cronbach's } \\
\text { Alpha }\end{array}$ & $\begin{array}{l}\text { Cronbach's Alpha Based } \\
\text { on Standardized Items }\end{array}$ & N of Items \\
\hline .926 & .931 & 27 \\
\hline
\end{tabular}

\subsection{Hypothesis Testing}

Hypothesis (\#1):

Ho: There is no significant relationship between human resource costing system and its role in assisting investors to appraise the human assets of a business enterprise.

One sample t-test was used to test our hypothesis. Table (3) shows that calculated $t=10.788$, which is higher than tabulated $\mathrm{t}=.000$ According to our decision rule : Accept Ho if calculated value is less than tabulated value and reject Ho if calculated value is higher than tabulated value. So we will reject Ho. So we can say that, there is significant relationship between human resource costing system and its role in assisting investors to appraise the human assets of a business enterprise.

\begin{tabular}{llllll}
\hline \multicolumn{8}{c}{ Test Value $=\mathbf{3}$} \\
\hline \multirow{2}{*}{$\mathrm{t}$} & Df & $\begin{array}{l}\text { Sig. } \\
(2 \text {-tailed })\end{array}$ & $\begin{array}{l}\text { Mean } \\
\text { Difference }\end{array}$ & $\begin{array}{l}\text { 95\% Confidence Interval } \\
\text { of the Difference } \\
\text { Lower }\end{array}$ & Upper \\
\hline 10.788 & 35 & .000 & .74306 & .6032 & .8829 \\
\hline
\end{tabular}

Hypothesis (\# 2): 
HO: There is no significant relationship between human resource costing system and the measurement of return on Investment ROI.

One sample t-test was used to test hypothesis (\#2). Table (4) shows that (calculated $t=10.874$ ), which is greater than tabulated t. According to our decision rule : Accept Ho if calculated value is less than tabulated value and reject Ho if calculated value is greater than tabulated value. So we will reject $\mathrm{Ho}$ and accept $\mathrm{Ha}$. So we can say that, there is significant relationship between human resource costing system and the measurement of return on Investment ROI.

\begin{tabular}{llllll}
\hline \multicolumn{8}{c}{ Test Value =3 } \\
\hline \multirow{2}{*}{$\mathrm{t}$} & df & $\begin{array}{l}\text { Sig. } \\
(2 \text {-tailed })\end{array}$ & $\begin{array}{l}\text { Mean } \\
\text { Difference }\end{array}$ & $\begin{array}{l}\text { 95\% Confidence Interval } \\
\text { of the Difference } \\
\text { Lower }\end{array}$ & Upper \\
\hline 10.874 & 35 & .000 & .80926 & .6582 & .9603 \\
\hline
\end{tabular}

\section{Conclusions \& Recommendations}

In order to build an actual human resources costing system, human resource costs concept and measurements, techniques should be established and well maintained. Human resource costs are sacrifices incurred to acquire or replace people. They have expense and assets components, just as any other cost does. The original cost of human resource is the sacrifice that was actually incurred to acquire and develop people. It typically includes costs of recruitment, selection, hiring, placement, orientation, and on-the- job training. Replacement costs refer to the sacrifice that would have to be incurred today to replace human resources presently employed. They typically include acquisition, learning and separation costs. Both original and replacement costs consist of direct and indirect, direct costs are cost traceable to a specified activity, while indirect costs are incurred for general use and are allocated to the activity. Outlay costs are actual cash expenditures while; opportunity costs refer to revenue foregone in acquiring or replacing people.

Current accounting practices for human assets causes an important problem to investors and management, because it distorts the measurement of return on investment. Since rate of return is the ratio of net income to total assets, it becomes distorted because of the distortions in its components. Investors who wish to base their decisions on an organizations rate of return should attempt to adjust for investments in human assets. Investments should be recognized in human resources which will allow management to calculate the rate of return on investment correctly and on a more comprehensive resource base for a particular profit center. To apply an actual human resources accounting system, companies should use the human resource costs concepts and measurements techniques in a good and effective manner while planning for the system, the nature of the company's industry, and its managerial philosophy.

\section{References}

[1] J. W. Boudreau and P. M. Ramstad. "Beyond HR: The New Science of Human Capital " Boston: Harvard Business School Press DOI: 10.1002/hrm.20291, 2009.

[2] Cascio, W. F. "Managing Human Resource: Productivity, quality of work life, profits" $9^{\text {th }}$ ed. New York: McGraw-Hill, 1998.

[3] Eric G. Flamholtz, "Human Resource Accounting: Advances in Concepts, Methods, and Applications" $3^{\mathrm{RD}}$ ed. Kluwer Academic Publisher, 1999.

[4] Cascio, W. F, 1998.

[5] William B. Werther and Keith Davis "Human Resources and Personnel Management" McGraw-Hill-New York, $5^{\text {th }}$ ed. 1996.

[6] Eric G. Flamholtz, 1999.

[7] Raymond J. Stone "Human Resources Management", John Wiley \& Sons Australia Ltd. $7^{\text {th }}$ ed. 2010.

[8] Wayne Cascio, John W. Boudreau "Investing in People: Financial Impact of Human Resource Initiatives" $2^{\text {nd }}$ ed. Pearson edu. Inc. 2010.

[9] William B. Werther and Keith Davis, 1996.

[10] Pareek, Udai "Evaluating human resource development" Jaipur. HRD Research Foundation. 1997.

[11] Eric G. Flamholtz, 1999.

[12] Wyne F. Cascio, "Costing Human Resources: The Financial Impact of Behavior in Organizations" South-Western College Publishing/Thomson Learning, $4^{\text {th }}$ ed. 2000.

[13] Eric G. Flamholtz, 1999.

[14] Eric G. Flamholtz, 1999.

[15] Eric G. Flamholtz, 1999.

[16] Parikh, Margie \& Gupta, Rajen, "Organizational behavior" TATA McGraw-Hill. 2010.

[17] Hermanson, R.H "Accounting for Human Assets" Occasional Paper No. 14, Graduate School of Business Administration, Michigan State University. 2004.

[18] Wyne F. Cascio, "Costing Human Resources" 2000.

[19] Lev, B. and Schwartz A. "On the Use of the Economic Concept of Human Capital in Financial Statements, Accounting Review, pp. 103-112.1971.

[20] Rensis Likert and David G. Bowers, "Improving the Accuracy of profit and loss reports by estimating the change in Dollar value of the human organization". Michigan business Review. 25 March. 1973.

[21] Jahmani, O.E., \& Al-Omari, A. "Implementing Cost Accounting Systems on Jordanian Banks: Field Study" Abhath Yarmouk University, 19(2). 2003.

[22] Hijazi, I., \& Ma'alem, S. Cost Accounting Through Activities. Dar Osama Publishers, Amman, Jordan. 20 